Journal of Mechanical, Civil and Industrial Engineering

ISSN: $2710-1436$

DOI: $10.32996 / j m c i e$

Journal Homepage: www.al-kindipublisher.com/index.php/jmcie

\title{
Augmented Reality-assisted Electronic Module for Ecology Student
}

\author{
Mahathir Muhammad ${ }^{1} \square$ Fatchur Rohman $^{2}$, Mimien Henie Irawati ${ }^{3}$, Bagus Priambodo ${ }^{4}$, Farid Akhasani ${ }^{5}$ \\ and Sofia Ery Rahayu ${ }^{6}$ \\ ${ }^{123456}$ Department of Biology Education, Faculty of Mathematics and Natural Sciences, Malang State University, Indonesia \\ $\square$ Corresponding Author: Mahathir Muhammad, E-mail: mahathirmuh.1903418@students.um.ac.id
}

\begin{abstract}
ARTICLE INFORMATION
Received: 08 October 2021

Accepted: 14 November 2021

Published: 18 November 2021

DOI: 10.32996/jmcie.2021.2.2.3

\section{KEYWORDS}

Electronic module

\section{ABSTRACT}

Education during the pandemic experiences many obstacles that hinder all learning processes. Learning in ecology courses, in particular, has problems because it has one of the activities students have to go to the environment to make observations. The environment referred to here is the Brantas River. Brantas River is the largest river in East Java. However, the river is polluted due to human activities around the river. This phenomenon is intended to be presented as a lesson material for students to be able to improve environmental attitudes. Augmented reality assistance is useful for moving the environment that will be the subject of student observation during virtual learning.
\end{abstract}

Augmented reality

Environmental Attitude Ecology

\section{Introduction}

Education inß Indonesia is based on Law No. 20 of 2003 which is clearly described in it that the direction of education and the purpose of education is to create students who are reliable and have the skills needed to solve problems in people's lives. One of the problems that become the focus of international discussion is environmental issues. According to (Partnership for 21St Century Learning 2007) one of the lessons that must be possessed by students is learning about science. One of the lessons in higher education is a course on ecology. The knowledge that will be obtained is about the environment on human life (Fauzi, Muryani, and Santosa 2018). Knowledge of the results of evaluating information about the environment will produce an environmental attitude (Omran 2014).

Education in the pandemic era is very difficult to present a real picture directly because distance learning makes it difficult for students to see objects directly. While education must give a real impression during the learning process. While the sources of information used by students almost resembled the situation before distance learning. Meanwhile, on interviews with influential lecturers, students' environmental attitudes have been measured and are still not good. The factors that cause poor environmental attitudes are due to poor human and environmental interactions caused by information and knowledge (Sujana, Hariyadi, and Purwanto 2018).

We can present related information about the environment by compiling teaching materials that give a real impression and help students learn well. This criterion is owned by the electronic module including self-instructional, self-contained, stand-alone. Adaptive, user-friendly, and consistent (Dikdasman 2017). Well-structured modules should also provide a learning effect. Augmented reality will give a good learning impression by giving a picture of the environment in reality but made virtually (Furht 2011). Education in the 21 st-century era should have started to get used to integrating technology into the educational process.

Electronic modules that are integrated with augmented reality are one of the technological innovations in the world of education. The electronic module has also been structured and added with augmented reality features that will give users flexibility in exploring information such as being in the environment directly (Rachmanto and Noval 2018). Moreover, in the current era, there are many sources that have been embodied in electronic sources, so this is also the reason for forming electronic modules so that students are helped by the structured learning process. (Rodin and Nurrizqi 2020).

Copyright: (c) 2021 the Author(s). This article is an open access article distributed under the terms and conditions of the Creative Commons Attribution (CC-BY) 4.0 license (https://creativecommons.org/licenses/by/4.0/). Published by Al-Kindi Centre for Research and Development, London, United Kingdom. 
Augmented reality means a real depiction that has been processed on an electronic device to be displayed virtually. In the process of making $A R$, there is numerous software needed to complete the visual creation process, including using Blender 3D and Unity 3D. (Nurrisma et al. 2021). Blender itself is software that plays a role in creating 3D shapes for images that have been taken in the real world (Rori, Sentinuwo, and Karouw 2016). As for Unity 3D, it is software to create applications of various kinds, either on desktop or mobile (Roedavan 2016). So, The data content contained here is data taken from the real environment, namely the herpetofauna community on the Brantas River for materials in ecology courses.

The research aims to create a learning medium in the form of an electronic module that is integrated with augmented reality which is a form of education that must take advantage of technological advances to support better education and have clear goals in the future. An electronic module that integrates augmented reality will be used by ecology students to observe the structure of the herpetofauna community in the Brantas River, East Java. Learning will be helped in the process of observing for distance learning.

\section{Method}

\subsection{Application Development Flowchart}

The flowchart of making AR in The Project-mahathir application can be seen in Figure 3.1. The first stage begins with preparing markers, modeling content, Unity 3D, and the Vuforia Package. The marker used in The Project-mahathir is a barcode that is accessed from the www.project-mahathir.com website. Then proceed with the creation and download of the marker dataset. Furthermore, data configuration is done with Unity 3D and Vuforia SDK. In the final stage, the project is compiled in the form of an application.

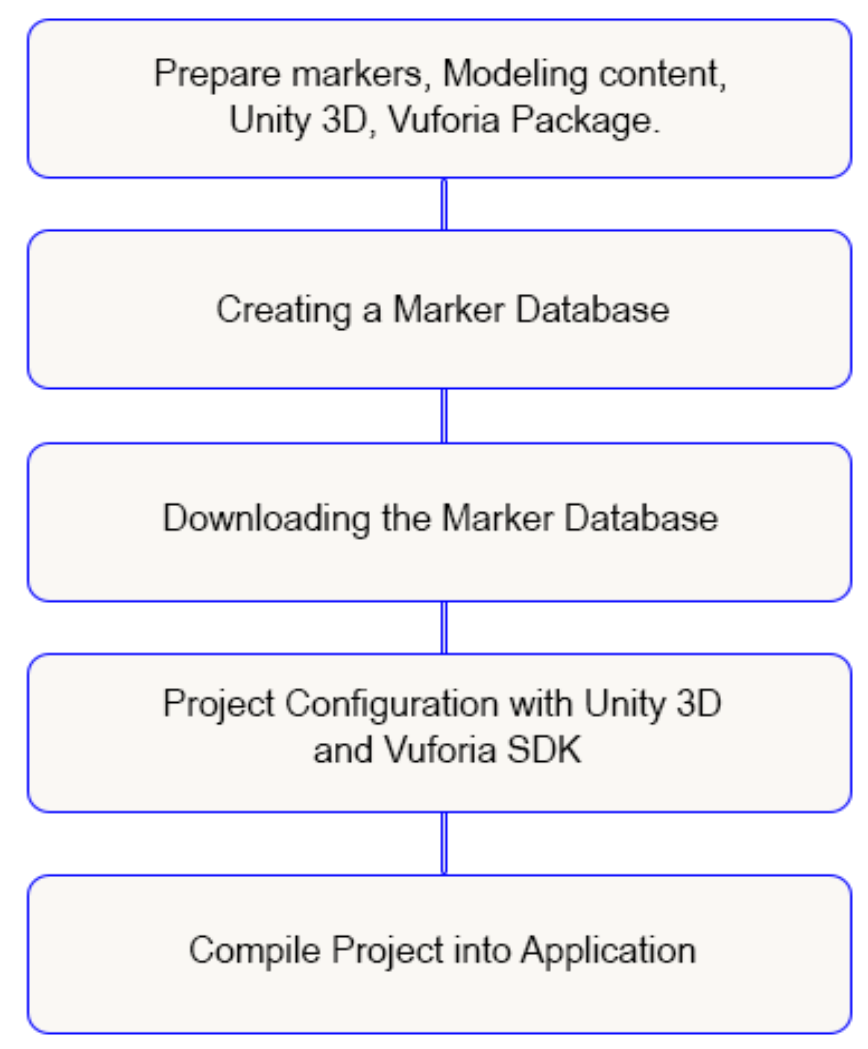

Figure 1. AR Application Creation Flowchart

\subsection{Use Case Diagram}

Use case diagrams illustrate user interactions with the system showing the relationship between users and the system. The following is the use case diagram of the AR in The Project-mahathir application. 


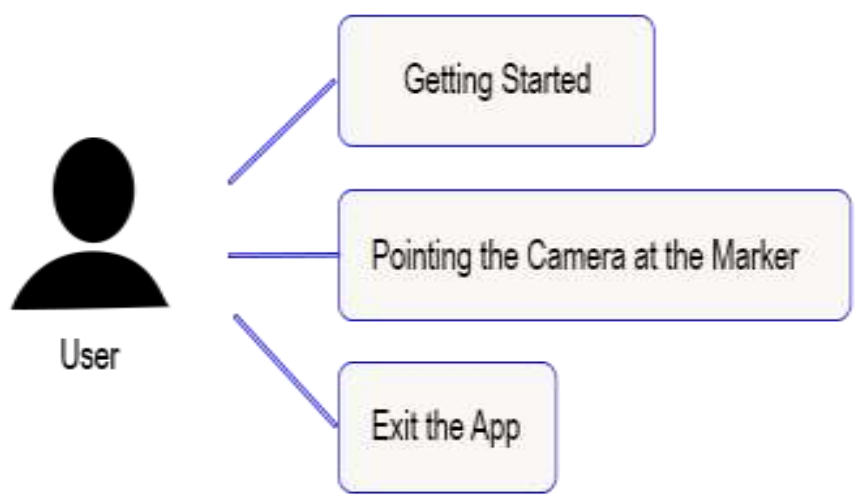

Figure 2. Use Case Diagram of AR Application

\subsection{Activity Diagram}

Activity diagram or activity diagram, which is a diagram that can model the processes that occur in a system where the process sequence is described vertically. The activity diagram is a development of the Use Case Diagram.

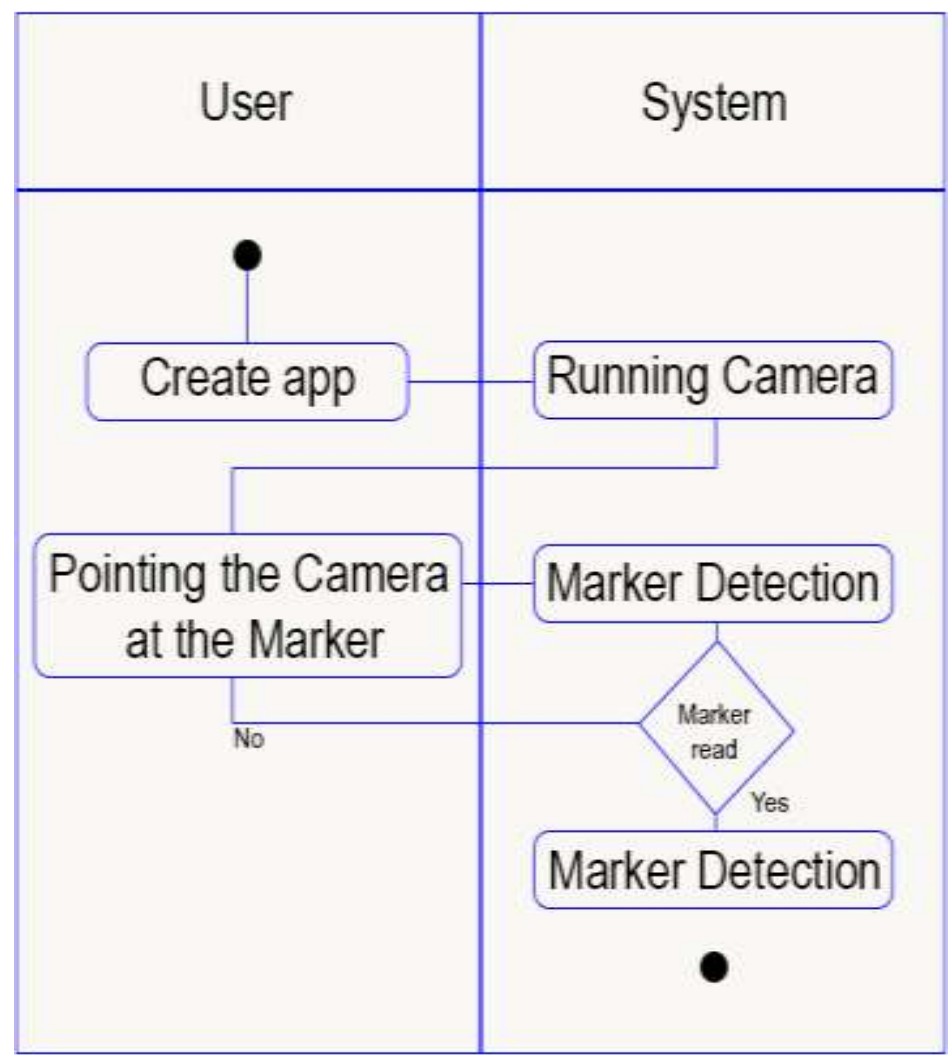

Figure 3. Activity Diagram of AR Application

\section{Results and Discussion}

Content retrieval is carried out upstream of the Brantas River. The data taken is data from the Brantas River community. The collection was carried out for one full month with two repetitions at different location points. The collection was carried out at night because the activities of the herpetofauna community were at night and classified as nocturnal animals. 
Figure 4. Survey activities and content data collection from left to bottom (a) Survey in Tulung Agung, (b) Survey in Blitar, and (c) Survey in Batu

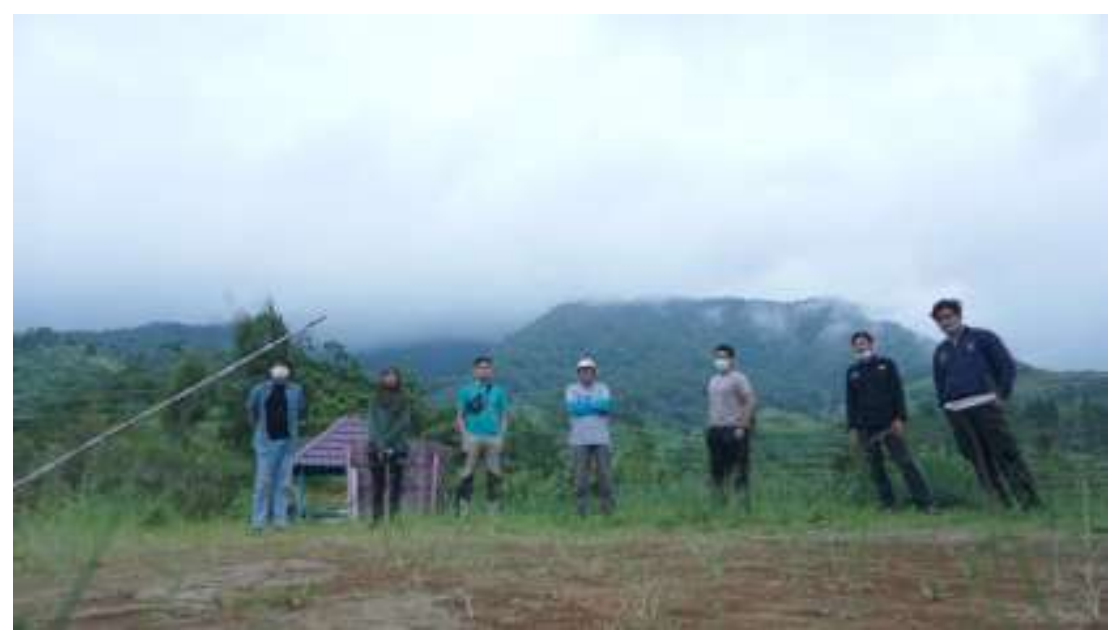

After the results of the animals are found and photos are taken and the names of the species are identified, they enter the process of making 3D media. This process is the creation of media that is like the objects we encounter in the real world. The following are the results of the real media to become something media, namely augmented reality that can be used in the observation process in class.

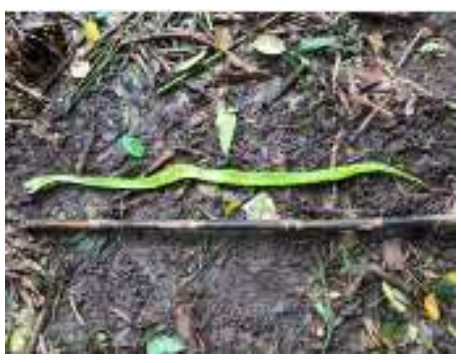

Figure 5. Real pictures of species

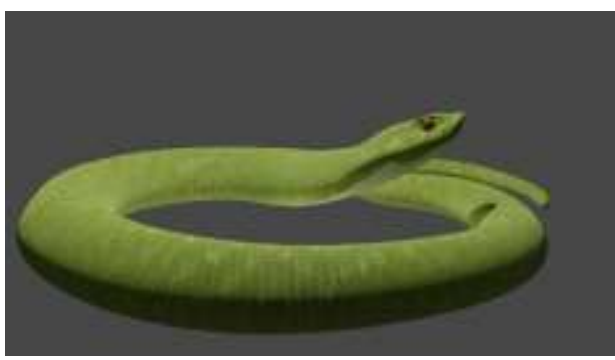

Figure 6. Species 3D Drawing

The process of using this augmented is that students must install an application that functions as a camera to be able to scan barcodes to be able to display 3D of each process. So that distance learning which is now applied to the world of education can continue to run. The better the learning received by students, the learning will be more meaningful (Napitupulu 2020). Augmented reality is an option in attracting students' attention because students are presented with a phenomenon that can be seen without having to explore the Brantas River. (Abidin, Hudaya, and Anjani 2020). Especially related to observations made by biology education students.

\section{Conclusion}

Based on the research, entitled Augmented reality which is integrated into the electronic module for ecology students, conclusions can be drawn. Integrating augmented reality into electronic modules as learning media to give a real impression in the student learning process in recognizing organisms that exist in the Brantas River environment with 3D animation models. Ecology students can study remotely because they can observe living things in the Brantas River and observe the interactions that occur by knowing the life patterns of each living thing.

\section{Acknowledgment}

This section can be written in case there are certain parties that need to be acknowledged, such as research sponsors. The acknowledgment must be written in brief and clear. In addition, avoid the hyperbole acknowledgment. 


\section{References}

[1] Abidin, Z, Adeng H, and Dinda A. (2020). EFEKTIVITAS PEMBELAJARAN JARAK JAUH PADA MASA PANDEMI COVID-19. Research and Development Journal of Education 1(1):131. doi: 10.30998/rdje.v1i1.7659.

[2] Dikdasman, D. (2017). Panduan Praktis Penyusunan E-Modul. Jakarta: Direktur Pembina SMA.

[3] Fauzi, M. I, Chatarina M, and Sigit S. (2018). HUBUNGAN ANTARA PENGETAHUAN LINGKUNGAN HIDUP DAN PRESTASI BELAJAR GEOGRAFI DENGAN SIKAP PEDULI LINGKUNGAN PADA SISWA SMA NEGERI DI KABUPATEN KARANGANYAR. GeoEco 4(1). doi: 10.20961/ge.v4i1.19184.

[4] Furht, B. (2011). Handbook of Augmented Reality. New York, NY: Springer New York.

[5] Napitupulu, R. M. (2020). Dampak pandemi Covid-19 terhadap kepuasan pembelajaran jarak jauh. Jurnal Inovasi Teknologi Pendidikan 7(1):23-33. doi: 10.21831/jitp.v7i1.32771.

[6] Nurrisma, N, Rizal M, Syahrial S. and Ernita M. (2021). Perancangan Augmented Reality dengan Metode Marker Card Detection dalam Pengenalan Karakter Korea. Informatika Mulawarman: Jurnal Ilmiah Ilmu Komputer 16(1):34. doi: 10.30872/jim.v16i1.5152.

[7] Omran, M. S. 2014. The Effect of Educating Environmental Ethics on Behavior and Attitude to Environment Protection. 3(3):141-50.

[8] Partnership for 21St-century Learning. (2007). Framework For 21st Century Learning.

[9] Rachmanto, A. D, and Sidiq N. (2018). IMPLEMENTASI AUGMENTED REALITY SEBAGAI MEDIA PENGENALAN PROMOSI UNIVERSITAS NURTANIO BANDUNG MENGGUNAKAN UNITY 3D. Jurnal Teknologi Informasi dan Komunikasi 9(1):29-37.

[10] Rodin, R, and Ade D. N. (2020). Tingkat Literasi Digital Mahasiswa Jurusan Ilmu Perpustakaan Dalam Pemanfaatan E-Resources UIN Raden Fatah Palembang. Pustakaloka 12(1):72-89. doi: 10.21154/pustakaloka.v12i1.1935.

[11] Roedavan, R. 2016. Unity Tutorial Game Engine. Bandung: Informatika.

[12] Rori, J, Steven R. S, and Stanley K. (2016). Perancangan Aplikasi Panduan Belajar Pengenalan Ortodonsia Menggunakan Animasi 3D. Jurnal Teknik Informatika 8(1). doi: 10.35793/jti.8.1.2016.12299.

[13] Sujana, K, Sugeng H., and Edy P. (2018). HUBUNGAN ANTARA SIKAP DENGAN PERILAKU PEDULI LINGKUNGAN PADA MAHASISWA. Jurnal Ecopsy 5(2):81-87. doi: http://dx.doi.org/10.20537/ecopsy.v5i2.5026. 